\title{
THE INFLUENCE OF TECHNOLOGY AND ACCOUNTING INFORMATION SYSTEMS DEVELOPMENT AGAINST THE ACCOUNTANT PROFESSION IN MINIMARKET PADANG
}

\author{
Sri Yuli Ayu Putri, Yuli Ardiany, Delori Nancy Meyla \\ Universitas Ekasakti \\ sriyuliayuputri@gmail.com
}

\begin{abstract}
Market agencies such as mini-markets require the use of accounting information systems. Mini-markets have thousands of products that are sold to the public in a variety of types to fulfill the needs of the community and reporting sales per day and purchasing goods from suppliers in the form of financial statements needed by management in a hasty manner.Seeing these conditions, one of the important things in managing a business unit is to make decisions using a computerized accounting information system. This research aims to know the effect of partially or simultaneously the technology and accounting information systems development on the accountant profession at the mini-market inPadang. The analytical method used is multiple linear regression analysis. I expect the outputs of this research to be published in the accredited National Journal and IPR publishing. Based on the results of the analysis and discussion of the influence of the Development of Accounting Information Technology and Systems on the Professional Absorption of Accountants, the following conclusions are, the development of technology partially influences the Professional Absorption of Accountants, accounting Information and the system partially has no effect on the Professional Absorption of Accountants.he development of Accounting Information Technology and System simultaneously influences the Professional Absorption of Accountants.
\end{abstract}

Keywords: Technology, Accounting Information Systems, and Professional Accountants.

\section{INTRODUCTION}

The Information Technology (IT) development is very rapid in the current era of globalization, which is increasingly advanced, as evidenced by the emergence of many technological devices to support people's lives. We created every innovation to provide positive benefits for human life. These developments also penetrated the field of information and various aspects of the organization's activities, without exception the organization sold retail goods.

Padang City is the capital of West Sumatra province, with the largest population in West Sumatra. With a large population, the need for personal equipment and basic needs is high. In this condition, there are big market 
EAJ (Economics and Accounting Journal) - Vol. 3, No. 3, Sept 2020 - Putri, Ardiany, Meyla

opportunities where one need is available at the mini-market.

Market agencies such as mini-markets require the use of accounting information systems. Mini markets have thousands of products that are sold to people with a variety of types in meeting the needs of the community. And reporting on day sales and purchase of goods from suppliers in the form of financial reports needed by management hastily. Seeing these conditions, the computerized accounting information system is one of the important things in managing a business unit to use as decision making.

One problem that often appears from the information technology development is the reduced use of human labor. Because the work has been done by the help of machines or systems that have been programmed with very little error

\section{LITERATURE REVIEW}

\subsection{Absorption of the Accountant Profession}

The meaning of absorption itself is defined as quite broad, absorbing labor in the meaning of gathering people or workers in a business field, to be able to suit the needs of the business itself.

A lot of workforce is available but cannot be absorbed by the industry, this is because the expertise of the workforce is not in accordance with what is needed by the industry, this is where the role of the government is needed to provide education or training for workers in order to have the skills needed by industry (Naisbitt, 2013: 44).

\subsection{Technological development}

The linkage of information development is defined as the linkage of the use of information technology infrastructure and the process of information technology management between business units together which consists of 4 indicators that complement rate to make the work far more effective and efficient than done by humans.

Even so, the role of accountants still cannot be eliminated within the company. It's because in preparing the accounting information system accountants are needed so that the system arranged under applicable regulations. For big companies, the accounting services needed are not as much as an era where information technology has not yet developed, companies only need accountants as system operators who will input financial data and the data processing is computerized.

Based on the discussion above this study interested to examine research on "The Influence of Technology and Accounting Information Systems Development Against the Accountant Profession in Minimarket in Padang".

each other namely (Kameswara Bayu, 2015: 5):

1. Information technology infrastructure

2. The process of preparing an information technology strategy

3. Information technology human resource management process

4. Management process management of information technology suppliers.

According to Azhar Susanto, the system is a collection / group of sub systems / parts / components of any physical or non-physical that are interconnected with each other and work together in harmony to achieve a certain goal. According to Mulyadi (2013: 3), the system is an organization of forms, records and reports that are coordinated in such a way as to provide financial information needed by management to facilitate the management of the company. 
EAJ (Economics and Accounting Journal) - Vol. 3, No. 3, Sept 2020 - Putri, Ardiany, Meyla

Accounting Information System Indicators:

1. System user satisfaction

2. System Usage

\section{Hypothesis}

Based on the picture above, a hypothesis can be formulated as follows: H1: Allegedly technological developments affect the accounting profession.

$\mathrm{H} 2$ : Allegedlythat the accounting information system influences the accounting profession.

H3: Allegedlythat the development of accounting technology and information systems simultaneously influences the accounting profession.

\section{RESEARCH METHOD}

\subsection{Data Collection Techniques}

This research is quantitative data in the form of processed data numbers from the answers to questionnaires using SPSS version 23.

The approach used in this study is a quantitative data approach that uses secondary data derived from books, questionnaires and other materials.

Data collection is carried out using field research methods. Data collection techniques are by interview and questionnaire. I conducted interviews with the owner and the finance department at the Padang City minimarket. Document research is carried out to strengthen field research. The research location is the mini-market area of Padang, West Sumatra.

\subsection{Sample Collection Techniques}

Population is a group consisting of objects or subjects that have certain qualities and characteristics determined by researchers to study and then drawn conclusions (Sugiyono, 2014: 17). The population used in this study is limited to only minimarkets or supermarkets in the city of Padang, which are registered in the Padang City Trade Office, as many as 30 minimarkets.

The sample is a portion of the population that has the same characteristics as the population. The number of samples from the population above was taken using a total sampling technique. The use of total sampling technique is because the total population is only 30 minimarkets in the city of Padang.

\subsection{Data AnalysisTechniques}

To test the research instrument, a validity and reliability test was conducted. Technical analysis method using the Classical Assumption Test using the normality test, multicollinity test, heteroscedasticity test and aMultiple linear regression analysis is used when the independent variables are more than one.

$\mathrm{B}$ form the equation as follows:

$$
\mathrm{Y}=\mathrm{b} 1 \mathrm{X} 1+\mathrm{b} 2 \mathrm{X} 2+\mathrm{e}
$$

Analysis of determination is simultaneously used to determine the degree of dependency together (simultaneously) between the independent variables and the dependent variables (Agussalim M, 2015), with the following formula:

$$
\begin{aligned}
& R_{(Y, X n)} \\
& =\frac{\text { Number of Regression Squares }}{\text { Total Number of Squares }}
\end{aligned}
$$

And to test the research hypothesis using the $\mathrm{T}$ Test and $\mathrm{F}$ Test.

\section{RESULTS AND DISCUSSION}

\subsection{Results}


EAJ (Economics and Accounting Journal) - Vol. 3, No. 3, Sept 2020 - Putri, Ardiany, Meyla

Table 1. Variable Descriptive

\begin{tabular}{|c|c|c|c|c|c|}
\hline \multicolumn{5}{|c|}{ Dependent Variable: Absorption of the Accountant Profession } & \multirow[b]{2}{*}{$\begin{array}{c}\text { Std. } \\
\text { Deviation }\end{array}$} \\
\hline Variable & $\mathrm{N}$ & Minimum & Maximum & The mean & \\
\hline $\begin{array}{l}\text { Technological } \\
\text { development }\end{array}$ & 30 & 55 & 94 & 83,13 & 9,126 \\
\hline $\begin{array}{c}\text { Accounting } \\
\text { Information System }\end{array}$ & 30 & 30 & 48 & 41,90 & 4,444 \\
\hline $\begin{array}{c}\text { Absorption of the } \\
\text { Accountant Profession }\end{array}$ & 30 & 15 & 25 & 21,40 & 2,343 \\
\hline Valid N (listwise) & 30 & & & & \\
\hline
\end{tabular}

Source : (10 pt Times New Roman and italic)

\subsection{Data analysis}

\subsubsection{Data Quality Test}

\section{a. Validity test}

By using the help of SPSS software version 23, the instrument validity testing, where the validity value shows in the Corrected Item-Total Correlation column. If the correlation number obtained is greater than 0.3 then the instrument is declared valid.

a. Technology Validity Test (X1)
Development 1) 
EAJ (Economics and Accounting Journal) - Vol. 3, No. 3, Sept 2020 - Putri, Ardiany, Meyla

\section{b. Validity of Accounting Information Systems (AIS) (X2)}

Table 3. Validity Test X2

\begin{tabular}{|l|r|r|r|}
\hline & $\begin{array}{l}\text { Corrected } \\
\text { Item-Total } \\
\text { Correlation }\end{array}$ & Valid Limits & Information \\
\hline X2.01 & 0.572 & 0.3 & Valid \\
X2.02 & 0.563 & 0.3 & Valid \\
X2.03 & 0.563 & 0.3 & Valid \\
X2.04 & 0.445 & 0.3 & Valid \\
X2.05 & 0.640 & 0.3 & Valid \\
X2.06 & 0.584 & 0.3 & Valid \\
X2.07 & 0.537 & 0.3 & Valid \\
X2.08 & 0.364 & 0.3 & Valid \\
X2.09 & 0.432 & 0.3 & Valid \\
X2.10 & 0.331 & 0.3 & Valid \\
\hline
\end{tabular}

Source: Results of SPSSv 23

\section{c. Validity Test of Professional Accountant Absorption(Y)}

Table 4. Validity Test $Y$

\begin{tabular}{|r|r|r|r|}
\hline & $\begin{array}{l}\text { Corrected } \\
\text { Item-Total } \\
\text { Correlation }\end{array}$ & Valid Limits & Information \\
\hline Y.01 & 0.553 & 0.3 & Valid \\
Y.02 & 0.489 & 0.3 & Valid \\
Y.03 & 0.432 & 0.3 & Valid \\
Y.04 & 0.355 & 0.3 & Valid \\
Y.05 & 0.318 & 0.3 & Valid \\
\hline
\end{tabular}

Source: Results of SPSSv 23

\subsubsection{Reliability Test}

This test is done by Cronbach Alpha statistical test which is a construct or variable said to be reliable if it gives a Cronbach Alpha value> 0.60 (Ghozali, 2016).
Table 5. Reliability Test

\begin{tabular}{|c|c|c|}
\hline Variable & $\begin{array}{l}\text { Cronbach's } \\
\text { Alpha }\end{array}$ & $\begin{array}{l}\mathrm{N} \text { of } \\
\text { Items }\end{array}$ \\
\hline $\mathrm{X} 1$ & 0.911 & 20 \\
\hline $\mathrm{X} 2$ & 0.815 & 10 \\
\hline Y & 0.672 & 5 \\
\hline
\end{tabular}

Source: Results of SPSSv 23

From the presentation of the table above it is known that the reliability test results of all research variables have a Cronbach's Alpha value of greater than 0.6 so that it is declared reliable and can be further tested.

\subsection{Classic assumption test \\ 4.3.1 Normality test}

The results of the normality test using the Kolmogorov-Smirnov One-Sample test can be seen in table.

Table 6. Normality Test Results

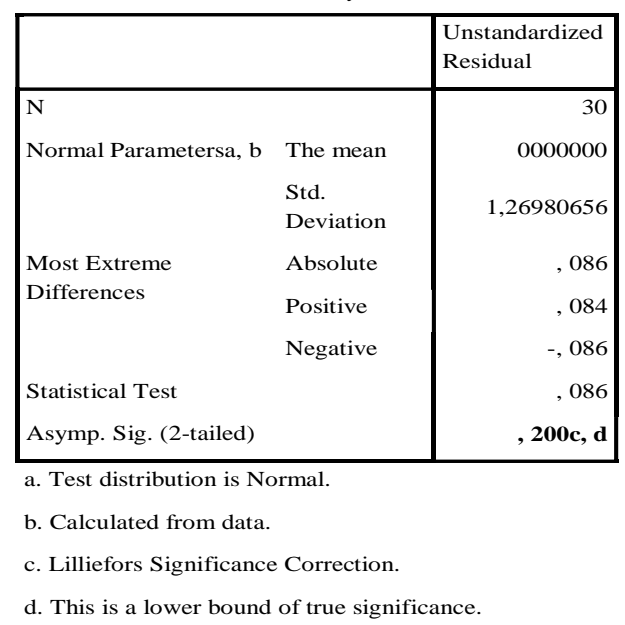

\subsubsection{Multicollinearity Test}

To detect multicollinearity can be seen from the Variance Inflation Factor (VIF). If the VIF value> 10, multicollinearity occurs. Conversely, if VIF <10, then multicollinearity does not occur (Ghazali, 2014). We can see the 
EAJ (Economics and Accounting Journal) - Vol. 3, No. 3, Sept 2020 - Putri, Ardiany, Meyla

results of multicollinearity test in this study in table 7 below:

Table 7. multicollinearity test

\begin{tabular}{|c|c|c|c|c|c|c|c|}
\hline \multirow[b]{2}{*}{ Model } & \multicolumn{2}{|c|}{$\begin{array}{l}\text { Unstandardized } \\
\text { Coefficients }\end{array}$} & \multirow{2}{*}{\begin{tabular}{|l|} 
Stand \\
ardize \\
$\mathrm{d}$ \\
Coeffi \\
cients \\
\\
Beta
\end{tabular}} & \multirow[b]{2}{*}{$\mathrm{t}$} & \multirow[b]{2}{*}{ Sig. } & \multicolumn{2}{|c|}{$\begin{array}{l}\text { Collinearity } \\
\text { Statistics }\end{array}$} \\
\hline & B & $\begin{array}{l}\text { Std. } \\
\text { Error }\end{array}$ & & & & $\begin{array}{l}\text { Toler } \\
\text { ance }\end{array}$ & VIF \\
\hline 1 (Constant) & 2,674 & 2,359 & & 1,134 & 0,267 & & \\
\hline $\mathrm{X} 1$ & 0,142 & 0,055 & 0,553 & 2,599 & 0,015 & 0,240 & 4,168 \\
\hline $\mathrm{X} 2$ & 0,165 & 0,112 & 0,313 & 1,470 & 0,153 & 0,240 & 4,168 \\
\hline
\end{tabular}

a. Dependent Variable: PROFESSION_AKUNTAN

To determine the multicollinearity test obtained from the column tolerance and VIF in the statistical collinearity section of table 4.7, so it can be concluded that:

a. The Technological Development Variable states there are no symptoms of multicollinearity because it has a VIF value of 4.168 which is smaller than 10 .

b. Accounting Information System perception variable stated there are no symptoms of multicollinearity because it has a VIF value of 4.168 which is smaller than 10 .

\subsubsection{Heteroscedasticity Test}

The following is a scatterplots chart to determine the presence or absence of heteroscedasticity:
Figure 1. Scatterplot graph

Scatterplot

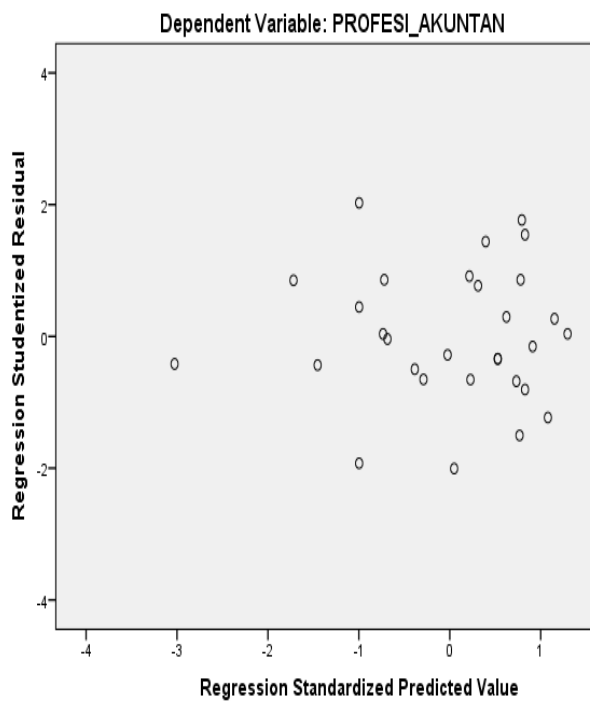

From scatterplots graphs shows that the points spread randomly and spread both above and below the number 0 on the $\mathrm{Y}$ axis. It can be concluded that there is no heteroscedasticity in the regression model so that the regression model is feasible to be used for further testing.

\subsection{Quantitative Analysis \\ 4.4.1 Linear Analysis Multiple}

The multiple linear regression equation that results from data processing is adopted from the coefficients table presented in table.

Table 8. Linear Analysis Multiple

\begin{tabular}{|c|c|c|c|c|c|c|c|}
\hline \multirow[b]{2}{*}{ Model } & \multicolumn{2}{|c|}{$\begin{array}{l}\text { Unstandardized } \\
\text { Coefficients }\end{array}$} & \begin{tabular}{|l} 
Stand \\
ardize \\
d \\
Coeffi \\
cients
\end{tabular} & & & \multicolumn{2}{|c|}{$\begin{array}{l}\text { Collinearity } \\
\text { Statistics }\end{array}$} \\
\hline & B & $\begin{array}{l}\text { Std. } \\
\text { Error }\end{array}$ & Beta & $\mathrm{t}$ & Sig. & $\begin{array}{l}\text { Toler } \\
\text { ance }\end{array}$ & VIF \\
\hline 1 (Constant) & 2,674 & 2,359 & & 1,134 & 0,267 & & \\
\hline $\mathrm{X} 1$ & 0,142 & 0,055 & 0,553 & 2,599 & 0,015 & 0,240 & 4,168 \\
\hline $\mathrm{X} 2$ & 0,165 & 0,112 & 0,313 & 1,470 & 0,153 & 0,240 & 4,168 \\
\hline
\end{tabular}

a. Dependent Variable: PROFESSION_AKUNTAN

From table 8 the results of multiple regression are obtained, namely: 
EAJ (Economics and Accounting Journal) - Vol. 3, No. 3, Sept 2020 - Putri, Ardiany, Meyla

$(Y)=2,674+0,142(X 1)+0.165(X 2)+e$

From the regression equation above can be described as follows:

1. Constant (absolute value of the Accountant Profession) if the variable Technology Development and Perceived Accounting Information System does not exist or worth 0 , then the Absorption of the Accountant Profession (Y) is 2,674 units.

2. The regression coefficient value of the variable Technological Development by 0.142 means that if there is an increase in the variable of Technological Development of one unit then the Absorption of Professional Accountancy increases by 0.142 units. Coefficient has a positive meaning between the variables of Technological Development and the Absorption of Professional Accountants with a positive effect.

3. The regression coefficient value of the variable of the Accounting Information System Perception of 0.165 means that if there is an increase in the variable of the Accounting Information System (AIS) by one unit, the Absorption of the Accounting Professional Profession increases by 0.165 units. Coefficient has a positive value which means that between the variable of the Accounting Information
System Perception and the Absorption of the Accountant Profession has no positive effect.

\subsubsection{Analysis Determination (R2)}

Table below shows the determination of the influence of Technology Development and Accounting Information Systems Perception on the Professional Absorption of Accountants. We can see the coefficient of determination of the variable Technology Development and Perception of Accounting Information Systems for the Absorption of Professional Accountancy in table.

Table 9. Analysis Determination

\begin{tabular}{|c|c|c|c|c|c|}
\hline Model & R & $\begin{array}{l}\mathrm{R} \\
\text { Square }\end{array}$ & $\begin{array}{l}\text { Adjusted } \\
\text { R Square }\end{array}$ & $\begin{array}{l}\text { Std. Error of } \\
\text { the Estimate }\end{array}$ & $\begin{array}{l}\text { Durbin- } \\
\text { Watson }\end{array}$ \\
\hline 1 & $0,840 \mathrm{a}$ & 0,706 & 0,685 & 1,316 & 1,949 \\
\hline \multicolumn{6}{|c|}{ a. Predictors: (Constant), SIA, PER_TEKNOLOGI } \\
\hline
\end{tabular}

Table 9 above shows the value of Adjust R Square Variable Technological Development and Accounting Information Systems Perception of the Professional Absorption of Accountants is 0.685 . From the results of the above table, known that the ability of the variable of Technology Development and Perception of Accounting Information Systems in explaining the variance of the Accountant Professional Absorption variable is $68.5 \%$. So that there are $31.5 \%$ variance in the Account Profession Absorption variable which is explained by other variables not examined in this study.

\subsection{Hypothesis test \\ 4.5.1 Test - $T$.}


EAJ (Economics and Accounting Journal) - Vol. 3, No. 3, Sept 2020 - Putri, Ardiany, Meyla

T test is used to test whether there is an individual significant influence of the independent variable on the dependent variable (Ghazali, 2014). T test results from this study can be presented in table.

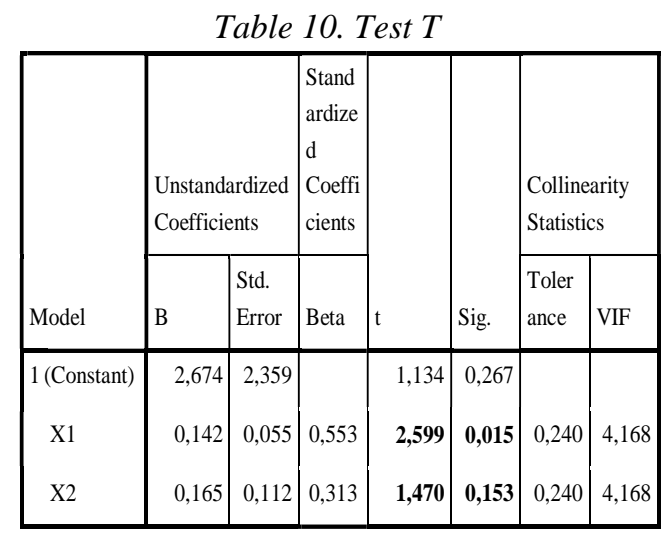

a. Dependent Variable: PROFESSION_AKUNTAN

a. The calculated $t$ value of the Technology Development variable is 2.599 value is greater than the $\mathrm{t}$ table value of 1.703. In addition, the probability value obtained is 0.015 which is smaller than the $\alpha(0.05)$ value used. Thus, it can be concluded that "Technological Development individually has a significant positive effect on the Absorption of Professional Accountants" received.

b. The $t$ value of the Accounting Information System Perception variable is 1.470 whose value is smaller than the $t$ table value of 1.703. In addition, the calculation of the probability value obtained is 0.153 greater than the value of $\alpha$ (0.05) used. Thus, it can be concluded that the perception of "Accounting Information Systems individually does not significantly influence the Absorption of Professional Accountants" is rejected.

\subsubsection{F-Test}

$\mathrm{F}$ test is done by looking at the calculated $F$ value and sig value.
ANOVA table of SPSSv output 23. Test results are presented in table.

Table 11 Test $F$

\begin{tabular}{|rl|r|r|r|l|l|}
\hline \multicolumn{2}{|l|}{ Model } & $\begin{array}{l}\text { Sum of } \\
\text { Squares }\end{array}$ & df & $\begin{array}{l}\text { Mean } \\
\text { Square }\end{array}$ & F & Sig. \\
\hline $1 \quad$ Regression & 112,440 & 2 & 56,220 & $\mathbf{3 2 , 4 6 3}$ & $\mathbf{0 , 0 0 0 b}$ \\
& Residual & 46,760 & 27 & 1,732 & & \\
Total & 159,200 & 29 & & & \\
\hline
\end{tabular}

a. Dependent Variable: PROFESSION_AKUNTAN

b. Predictors: (Constant), SIA, PER_TEKNOLOGI

From the table it is known that the calculated $F$ value of 32.463 is greater than the $\mathrm{F}$ table value of 2.92 ( $\mathrm{df}=30$, in the appendix table F) and the sig value resulting from the calculation is 0,000 which is smaller than the $\alpha$ used by 0.05 $(5 \%)$.

Thus, it can be concluded that the variable "The Development of Accounting Information Technology and Systems simultaneously / together has a significant effect on the Professional Absorption of Accountants".

\subsection{Discussion}

The calculated $t$ value of the Technology Development variable is 2.599 value is greater than the table value of 1.703. In addition, the probability value obtained is 0.015 which is smaller than the $\alpha(0.05)$ value used. Thus, it can be concluded that "Technological Development individually has a significant positive effect on the Absorption of Professional Accountants" received.

The $\mathrm{t}$ value of the Accounting Information System Perception variable is 1.470 whose value is smaller than the $\mathrm{t}$ table value of 1.703. In addition, the calculation of the probability value obtained is 0.153 greater than the value of $\alpha(0.05)$ used. Thus, it can be concluded that the perception of "Accounting Information Systems 
EAJ (Economics and Accounting Journal) - Vol. 3, No. 3, Sept 2020 - Putri, Ardiany, Meyla

individually does not significantly influence the Absorption of Professional Accountants" is rejected.

\section{CONCLUSION}

Based on the results of the analysis and discussion of the influence of the Development of Accounting Information Technology and Systems on the Professional Absorption of Accountants,

\section{REFERENCE}

Abdul, H \& Bambang S, (2015). Management Accounting, Issue 6, Eleventh Printing, BPFE, Yogyakarta.

Abdul, K. (2014). Introduction of Information Systems Revised Edition. Andi.Yogyakarta.

Agung, M. (2018). The Impact of ECommerce Development on the Role of Management Accountants

Agus, M. (2015). Continuing Statistics, Ekasakti Press, Padang

Akbar, S. (2017). The Effect of Auditor Experience, Audit Complexity, and Time Budget Pressure on Audit Quality with Variable Moderating Understanding of Information Systems (Empirical Study on Public Accountants in Pekanbaru, Medan and Padang).

Arikunto, S. (2014). Research Procedure: A Practice Approach. Jakarta: Rineka Cipta

Azhar, S. (2013). Accounting Information Systems. Bandung: Lingga Jaya.

Baridwan, Z. (2013). Accounting System Formulation Procedures and Methods. Yogyakarta: YKPN.

Bonita, W. (2018). Analysis of the Professional Accounting Firm (KAP) Professional Code of Ethics in KapSudiyono\& Vera Samarinda the following conclusions are:

1. The development of technology partially influences the Professional Absorption of Accountants.

2. Accounting Information System partially has no effect on the Professional Absorption of Accountants.

3. The development of Accounting Information Technology and System simultaneously influences the Professional Absorption of Accountant.

Dhinu P. (2013). The Effect of Information Technology Progress on Accounting Development, STIE Dharmaputra Semarang.

Diana, R. (2013). The Role of Information Technology in the Relationship of Organizational Structure and Environment, Yogyakarta State University.

Ghozali, I. (2014). Multivariate Analysis Applications with the IBM Program. SPSS 20 (fifth edition.) Semarang: Diponegoro University.

Hall, A. (Dewi Fitriasari and Deny Arnos Kwary, Translator). (2013). Accounting Information Systems. Issue 4. Jakarta: Salemba Empat.

Herold, M. (2013). The Role of Information Technology in the Development of the Business World in Indonesia, Adventist University of Indonesia.

Intan, K. (2018). The Effect of Information Technology Utilization on Individual Performance in Surakarta City Bappeda Office

Kameswara B. (2015). The Influence of Information Technology Relations to Company Performance with Knowledge Management Capabilities as Mediating Variables, Muhammadiyah University, Surakarta.

Miarso, Y. (2013). Sowing the Seed of 
EAJ (Economics and Accounting Journal) - Vol. 3, No. 3, Sept 2020 - Putri, Ardiany, Meyla

Educational Technology, Jakarta: Kencana.

Miktam, N. (2018). Analysis of Raw Material Inventory Accounting Information System

Muhammad, T. (2017). The Influence of Information Technology in Professionalism and Its Implications in the World of Education, Muhammadiyah University, Tasikmalaya.

Mulyadi. (2014). Management Development of the Accounting Profession in Indonesia.

Rudianto. (2016). Management Accounting: Information for Management Decision Making, Editor Surya Ubha, Grasindo, Jakarta.

Sugiyono. (2013). Business Research Methods. Bandung: Alfabeta.

Tulus, T. (2014). Indonesian Economy. Jakarta: Ghalia Publisher

Sabihaini. (2014). Analysis of Utilization of Information Technology and Individual Performance (Study at Hospitals in Yogyakarta). Widya Journal of Management and Accounting

Tata, S. (2014). Information Systems Analysis. Andi. Yogyakarta.

Tjiptono, F. (2013). Marketing Strategy, ANDI: Yogyakarta.

Triana, B. (2018). The Effect of
Accounting. Seventh Edition. Thirteenth Matter. Salemba Empat. Jakarta.

Nana \& Philips, (2013). High Tech, High Touch. Bandung: Mizan.

Rifki, D. (2013). The Effect of Contemporary Business Environment on Cost Management, Gajah Mada University, Yogyakarta.

Rina, A. (2014). The Effect of Information Technology on the Electronic Data Processing Systems Sales and Information Technology Support on the Effectiveness of Internal Sales Control at PT. Intan Jaya Garments District Semarang

Unti, L. (2017). Accountant Ethics Paradox, Yogyakarta: Student Library

Widjajanto, N. (2013). Accounting Information Systems. Erlangga: Jakarta.

Zelda, T. (2018). The Influence of Accounting Information Systems and Internal Control Systems on the Quality of Regional Financial Statements (Study at Bandar Lampung City and Metro City Offices).

Constitution :

Law No. 20 of 2008 concerning MSMEs 